DOI:10.17951/h.2021.55.3.67-80

\begin{tabular}{lcc}
\hline \multicolumn{1}{c}{ A N N A L E S } \\
UNIVERSITATIS MARIAE CURIE-SKŁODOWSKA \\
LUBLIN - POLONIA \\
VOL. LV, 3 & SECTIOH H \\
\hline
\end{tabular}

\author{
KATARZYNA MAMCARZ \\ katarzyna.mamcarz@mail.umcs.pl \\ Maria Curie-Skłodowska University. Faculty of Economics \\ 5 Maria Curie-Skłodowska Sq., 20-031 Lublin, Poland \\ ORCID ID: https://orcid.org/0000-0001-9195-3410
}

\title{
Granger Causality between Stock and Gold Returns - Evidence from Poland, Hungary and the Czech Republic
}

Keywords: stock indices; domestic gold price; Granger causality; VAR models

JEL: G11; G15; C32

How to quote this paper: Mamcarz, K. (2021). Granger Causality between Stock and Gold Returns Evidence from Poland, Hungary and the Czech Republic. Annales Universitatis Mariae Curie-Skłodowska, sectio H-Oeconomia, Vol. 55, No. 3.

\footnotetext{
Abstract

Theoretical background: The safety of capital investments is one of the criteria in the decision-making process. Under conditions of uncertainty in financial market, investors' interest in gold - as an alternative form of capital investment - is growing, especially in comparison with stocks perceived as more risky assets. Fluctuations in the prices of these assets make investors transfer their funds from gold markets to more profitable markets, or return to gold markets. From this point of view, it is important to analyse the causal relationships between returns on these assets.

Purpose of the article: The aim of this paper is to investigate the causal relationship between the rates of return on investment in gold and stocks in selected countries of Central and Eastern Europe (Poland, Hungary, and the Czech Republic). We assume that the rates of return on the gold market constitute a Granger cause of the rates of return on the analysed stock markets.

Research methods: To investigate the impact of the gold market on the stock market and vice versa, including the type and direction of Granger causality of the rates of returns, the VAR models were estimated and served as the basis for performing a Granger non-causality linear test. The analysis of stationarity (ADF test) and cointegration (the Johansen test) of variables was carried out to select the final form of VAR/ VECM model. The empirical data covered the period between December 1996 and December 2020. The
} 
analysis was carried out for the entire period and two sub-periods: the first one before the 2007 financial crisis and the second one, covering this crisis and the beginning of the ongoing COVID-19 pandemic. Stock indices included in this research are composed of the most liquid stocks, so-called blue chip shares traded on the Warsaw Stock Exchange - WIG20, the Budapest Stock Exchange - BUX index, the Prague Stock Exchange - PX index. The gold prices are expressed in domestic currencies (PLN, HUF, CZK, respectively). Monthly logarithmic returns on investment on the analysed markets constituted the variables of models reflecting the interrelations in the considered countries.

Main findings: We show that, apart from two instances of unilateral causality running from gold to stock returns, no causal relationships were found in any of the directions (independence) for the entire sample. We prove that in the case of Hungary and the Czech Republic (significant at $\alpha=5 \%$ ), the rate of return on the gold market determined the rates of return on the stock market, whereas in Poland, no such causality was identified. To some extent, the research hypothesis was positively verified. The results also confirm that changes in the stock market prices in all considered countries did not affect the change in the price of gold. After dividing the sample into two sub-periods, no causal relationships were found between the analysed markets in the first sub-period, whereas in the second sub-period, we indicate that the rates of return on gold determine the rates of return on stocks in two countries, namely Poland and Hungary. In this respect, the research hypothesis of one-way causality occurring in the analysed sub-periods is positively verified. Only in Hungary is the impact of gold on the stock market observed both in the entire period and in the second sub-period.

\section{Introduction}

Gold can be perceived as an alternative form of capital investment in comparison with stocks, since it demonstrates a low or negative correlation with them. The role of gold is increasing during instability in financial markets (a financial crisis or a pandemic). Low rates of return characteristic to bear stock markets encourage investors to shift to gold, considered as a relatively safe investment (safe haven) (Beckmann, Berger, \& Czudaj, 2015), whereas rising stock prices weaken investors' interest in this precious metal. Therefore, it is important to analyse the linkages between stock and gold markets.

The aim of this paper is to investigate the causal relationship (Granger causality) between the rates of return on investment in gold and stock market in selected countries of Central and Eastern Europe (Poland, Hungary, and the Czech Republic). We decided to analyse the financial markets in this part of Europe as the mentioned countries are rarely the subject of empirical research. Most studies devoted to the relations between various classes of assets and gold, especially the interrelations stock - gold, focus on countries which are in particular the major producers like China, Australia, Russia, the US and Canada and the consumers of gold such as India, China, the US, Switzerland and Germany as well as other geographical areas: North America, Asia, Oceania and the Middle East according to GFMS (2019) and WGC. The researchers achieve mixed results and they indicate various types of Granger causality between the analysed assets: unidirectional ${ }^{1}$ (e.g. Açikalin \& Başci, 2016;

\footnotetext{
1 In this case, two alternative directions are possible, i.e. from asset $\mathrm{Y}$ to $\mathrm{X}$ or vice versa.
} 
Hemavathy \& Gurusamy, 2016), bidirectional (Mishra, Das, \& Mishra, 2010) and independence (Bhuvaneshwari \& Ramya, 2017).

We formulate the following research hypothesis for three countries of interest: rates of return on the gold market constitute a Granger cause of the rates of return on the analysed stock markets (unidirectional causality from gold to stock returns). To verify this assumption, we apply the VAR models which serve as the basis for performing a Granger non-causality linear test. The empirical data cover the period between December 1996 and December 2020, including the beginning of the COVID-19 pandemic. We also distinguish two sub-periods: the pre-financial crisis (December 1996 to June 2007) and the next period (July 2007 to December 2020), including the crisis of 2007 and the beginnings of the ongoing COVID-19 pandemic. Indices included in this research consist of the most liquid stocks, so-called blue chip shares traded on the Warsaw Stock Exchange - WIG20, the Budapest Stock Exchange - BUX index, the Prague Stock Exchange - PX index. Investors treat these indices as the benchmarks for diversified portfolios of stocks as an underlying instrument for derivatives. Gold prices were expressed in domestic currencies of the countries mentioned above: PLN, HUF and CZK, respectively. On this basis, the monthly rates of return are calculated to reflect the profitability of investments on the analysed markets.

\section{Literature review}

In the literature review we focus mainly on presenting the results of the studies carried out by the authors who investigate the interrelationships between the gold and stock market (regional and international) returns, covering different research periods and the methods applied (Table 1).

Table 1. Results of research of causality between gold and stock market by selected author(s)

\begin{tabular}{|l|l|l|l|l|l|}
\hline Author(s) / year & \multicolumn{1}{|c|}{ Period } & Country & Method & \multicolumn{1}{|c|}{ Variables } & \multicolumn{1}{|c|}{ Results } \\
\hline $\begin{array}{l}\text { Mishra et al. } \\
(2010)\end{array}$ & $\begin{array}{l}\text { Jan. 1991 } \\
\text { - Dec. } \\
2009\end{array}$ & India & VECM & $\begin{array}{l}\text { Gold prices and } \\
\text { stock market returns } \\
\text { based on BSE 100 } \\
\text { index }\end{array}$ & $\begin{array}{l}\text { A feedback causality (gold prices, } \\
\text { Granger cause stock market } \\
\text { returns and vice versa). }\end{array}$ \\
\hline $\begin{array}{l}\text { Miyazaki and } \\
\text { Hamori (2013) }\end{array}$ & $\begin{array}{l}\text { Jan. 2000 } \\
- \text { Apr. } \\
2011\end{array}$ & US & $\begin{array}{l}\text { AR- } \\
\text { EGARCH } \\
\text { model, } \\
\text { Hong's } \\
\text { test } \\
\text { causality } \\
\text { in mean/ } \\
\text { variance } \\
\text { and CCF } \\
\text { approach }\end{array}$ & $\begin{array}{l}\text { Gold price USD } \\
\text { (LBMA, PM fixing), } \\
\text { S\&P 500 index }\end{array}$ & $\begin{array}{l}\text { A unidirectional causality in mean } \\
\text { from S\&P 500 to gold but no cau- } \\
\text { sality in variance in both directions } \\
\text { (entire sample). } \\
\text { A bidirectional causality in mean } \\
\text { but no causality in variance in } \\
\text { any of the directions (pre-crisis } \\
\text { period). } \\
\text { A unilateral causality both in mean } \\
\text { and variance running from stock to } \\
\text { gold (post-crisis period). }\end{array}$ \\
\hline
\end{tabular}


Pobrane z czasopisma Annales $\mathrm{H}$ - Oeconomia http://oeconomia.annales.umcs.pl

Data: 26/04/2023 06:29:40

\begin{tabular}{|c|c|c|c|c|c|}
\hline Author(s) / year & Period & Country & Method & Variables & Results \\
\hline $\begin{array}{l}\text { Hussin, } \\
\text { Muhammad, } \\
\text { Razak, Tha, and } \\
\text { Marwan (2013) }\end{array}$ & $\begin{array}{l}\text { Jan. } 2007 \\
- \text { Dec. } \\
2011\end{array}$ & Malaysia & VAR & $\begin{array}{l}\text { Crude Oil Price } \\
\text { (COP), Kijang Gold } \\
\text { Price (KGP), and } \\
\text { FTSE Bursa Malay- } \\
\text { sia Emas Shariah } \\
\text { Index (FBMES) }\end{array}$ & $\begin{array}{l}\text { No causality between FBMES and } \\
\text { gold prices. } \\
\text { No cointegration between the rates } \\
\text { of return on investment in the } \\
\text { Islamic stocks and in the strategic } \\
\text { commodities in the long run. }\end{array}$ \\
\hline Patel (2013) & \begin{tabular}{|l} 
Jan. 1991 \\
- Dec. \\
2011 \\
\end{tabular} & India & VECM & $\begin{array}{l}\text { Gold, Sensex, BSE } \\
\text { 100, S\&P CNX } \\
\text { Nifty }\end{array}$ & $\begin{array}{l}\text { A Granger causality between gold } \\
\text { and the Nifty index. }\end{array}$ \\
\hline $\begin{array}{l}\text { Choudhry, Has- } \\
\text { san, and Shabi } \\
(2015)\end{array}$ & \begin{tabular}{|l|} 
Jan. 2000 \\
- Mar. \\
$2014 ;$ \\
Two \\
sub-pe- \\
riods, \\
before and \\
during \\
the crisis \\
(2007) \\
\end{tabular} & $\begin{array}{l}\text { UK, US, } \\
\text { Japan }\end{array}$ & GARCH & $\begin{array}{l}\text { Rates of return on } \\
\text { gold in national cur- } \\
\text { rencies and stocks, } \\
\text { and their volatility }\end{array}$ & $\begin{array}{l}\text { A non-linear bilateral correlation } \\
\text { (crisis period). } \\
\text { A significant causality before the } \\
\text { crisis (UK) and during the crisis } \\
\text { (Japan). }\end{array}$ \\
\hline $\begin{array}{l}\text { Gokmenoglu } \\
\text { and Fazlollahi } \\
\text { (2015) }\end{array}$ & $\begin{array}{l}\text { Jan. } 2013 \\
- \text { Nov. } \\
2014\end{array}$ & US & ARDL & $\begin{array}{l}\text { S\&P 500, gold price, } \\
\text { oil price; } \\
\text { gold price volatility } \\
\text { (GVZ) and oil price } \\
\text { volatility (OVX) }\end{array}$ & $\begin{array}{l}\text { A bilateral causality between } \\
\text { changes of gold price and S\&P } \\
500 .\end{array}$ \\
\hline $\begin{array}{l}\text { Açikalin and } \\
\text { Başci (2016) }\end{array}$ & $\begin{array}{l}1 \text { Aug. } \\
2012-17 \\
\text { Mar. } 2015\end{array}$ & Turkey & VECM & $\begin{array}{l}\text { BIST Gold Market } \\
\text { Index, Stock Index } \\
\text { (BIST 100) }\end{array}$ & $\begin{array}{l}\text { A unidirectional Granger causal } \\
\text { relationship between BIST } 100 \\
\text { and gold. } \\
\text { A long-term equilibrium (BIST } \\
100 \text { index, gold). }\end{array}$ \\
\hline $\begin{array}{l}\text { Hemavathy } \\
\text { and Gurusamy } \\
\text { (2016) }\end{array}$ & $\begin{array}{l}\text { Apr. } 2002 \\
\text { - Mar. } \\
2015 \\
\end{array}$ & India & VECM & $\begin{array}{l}\text { S\&P CNX Nifty and } \\
\text { gold }\end{array}$ & $\begin{array}{l}\text { A unidirectional causality from } \\
\text { gold to stocks; } \\
\text { Co-integration existed. }\end{array}$ \\
\hline $\begin{array}{l}\text { Bhuvaneshwari } \\
\text { and Ramya } \\
\text { (2017) }\end{array}$ & \begin{tabular}{|l} 
Jan. 2011 \\
- Dec. \\
2015 \\
\end{tabular} & India & VAR & $\begin{array}{l}\text { S\&P CNX Nifty and } \\
\text { gold market }\end{array}$ & $\begin{array}{l}\text { No causal relationship. } \\
\text { No cointegration. }\end{array}$ \\
\hline $\begin{array}{l}\text { Al-Ameer, } \\
\text { Hammad, } \\
\text { Ismail, and } \\
\text { Hamdan (2018) }\end{array}$ & $\begin{array}{l}\text { Aug. } 2004 \\
\text { - Sep. } \\
2016\end{array}$ & Germany & VAR & $\begin{array}{l}\text { Gold price, FSE } \\
\text { HDAX Index }\end{array}$ & $\begin{array}{l}\text { No Granger causality. } \\
\text { A long-run relationship. }\end{array}$ \\
\hline $\begin{array}{l}\text { Al Kharusi and } \\
\text { Basci (2019) }\end{array}$ & $\begin{array}{l}2010- \\
2016\end{array}$ & 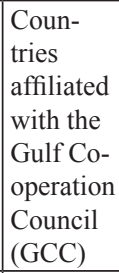 & VAR & $\begin{array}{l}\text { Gold prices, } \\
\text { the stock } \\
\text { markets indices of } \\
\text { GCC countries }\end{array}$ & $\begin{array}{l}\text { A Granger causality: } \\
\text { five instances of bilateral corre- } \\
\text { lation, } \\
\text { nine instances of unilateral corre- } \\
\text { lation. }\end{array}$ \\
\hline $\begin{array}{l}\text { Mamcarz } \\
(2019)\end{array}$ & $\begin{array}{l}\text { Jan. } 1997 \\
\text { - Mar. } \\
2018\end{array}$ & $\begin{array}{l}\text { US, Ger- } \\
\text { many, } \\
\text { Japan, } \\
\text { Poland } \\
\end{array}$ & VAR & $\begin{array}{l}\text { Gold, S\&P 500, } \\
\text { DAX, NIKKEI, } \\
\text { WIG }\end{array}$ & $\begin{array}{l}\text { The cases of bidirectional, unidi- } \\
\text { rectional causality and indepen- } \\
\text { dence depending on selected } \\
\text { periods and countries. }\end{array}$ \\
\hline
\end{tabular}


Pobrane z czasopisma Annales H - Oeconomia http://oeconomia.annales.umcs.pl Data: 26/04/2023 06:29:40

GRANGER CAUSALITY BETWEEN STOCK AND GOLD RETURNS - EVIDENCE FROM POLAND...

\begin{tabular}{|c|c|c|c|c|c|}
\hline Author(s) / year & Period & Country & Method & Variables & Results \\
\hline $\begin{array}{l}\text { Tiwari, } \\
\text { Adewuyi, and } \\
\text { Roubaud (2019) }\end{array}$ & $\begin{array}{l}\text { Jan. } 2002 \\
- \text { July } \\
2018\end{array}$ & $\begin{array}{l}\text { Brazil, } \\
\text { China, } \\
\text { India, } \\
\text { Korea, } \\
\text { Indo- } \\
\text { nesia, } \\
\text { Mexico, } \\
\text { Russia, } \\
\text { Turkey }\end{array}$ & $\begin{array}{l}\text { QQ re- } \\
\text { gression } \\
\text { methods }\end{array}$ & $\begin{array}{l}\text { Gold and stock } \\
\text { returns for analyzed } \\
\text { markets }\end{array}$ & $\begin{array}{l}\text { No causality priori crisis. } \\
\text { The cases of unidirectional causal- } \\
\text { ity from gold to stocks in some of } \\
\text { the markets after the crisis. }\end{array}$ \\
\hline
\end{tabular}

Source: Author's own study based on the literature.

The results confirm the existence of bidirectional relationship as well as unidirectional Granger causality running from gold to stocks or in the opposite direction. Also the lack of causality in either direction is documented. In general, they varied depending on the research period and its sub-periods, and countries or regions under analysis.

In some cases, authors achieved divergent results among countries, e.g. Choudhry et al. (2015) for the United Kingdom, the United States and Japan, and Mamcarz (2019) for the United States, Germany, Japan and Poland. Consistent results were reported by Al Kharusi and Basci (2019) for countries affiliated with the Gulf Cooperation Council (GCC) - Bahrain, Kuwait, Oman, Qatar, Saudi Arabia, and the United Arab Emirates, and Tiwari et al. (2019), who focused on interrelations in Brazil, China, India, Korea, Indonesia, Mexico, Russia and Turkey. Findings presented by Patel (2013) and Hemavathy and Gurusamy (2016), in the case of the Indian market, are also similar; however, they are not consistent with the results presented by Bhuvaneshwari and Ramya (2017) who identified no Granger causal relationship between S\&P CNX Nifty and gold, and show the lack of a long-term relationship between the analysed variables. On the other hand, Mishra et al. (2010) report the feedback causality between gold and stock market returns.

This confirms that the results are sensitive to the considered period which can impact on the nature of the relationship between the analysed time series. When research was devoted to a particular country, for instance, Germany (Al-Ameer et al., 2018) or Turkey (Açikalin \& Başci, 2016), the long-run relationship was identified in both cases; however, only in the latter case was the Granger causality running from stock to gold confirmed. In contrary to the results presented above, according to Hussin et al. (2013), stock prices are not the Granger cause of gold price. Moreover, they show no cointegration between Islamic stock returns and strategic commodities in the long run. While analysing the US market, Miyazaki and Hamori (2013) as well as Gokmenoglu and Fazlollahi (2015) achieve mixed results. Miyazaki and Hamori (2013) indicate unidirectional causality in mean running from S\&P 500 to gold, but no causality in variance in both directions for the entire sample but Gokmenoglu and Fazlollahi (2015) show the existence of bilateral causality between changes of gold price and S\&P 500, however, for a much shorter period under investigation. 
The common research method applied in the reviewed literature was the estimation of VAR (Vector Autoregression Model) or VECM (Vector Error Correction Model) in the case of cointegrated variables (long-run relationship), as the basis for the Granger no-causality test. The analysis of the interrelations was preceded by a time series stationarity test (ADF test) and cointegration analysis (the Johansen test). The model of ARCH classes are also used: the Generalized Autoregressive Conditional Heteroskedasticity Model (GARCH), a model based on adjusting an AR process to the Exponential GARCH (AR-EGARCH). The quantile-on-quantile (QQ) approach and the Autoregressive Distributed Lag Model (ARDL) were also employed in the research presented above.

We emphasize that there is difficulty in comparability of findings due to the different time horizons and geographical areas of interest as well as models applied in research determined by characteristics of time series (VAR vs. VECM).

\section{Research method and data}

We analyse the causal relationship between stock and gold markets by applying the reduced-form of the $p$ th-order two-dimensional Vector Autoregressive Model, $\operatorname{VAR}(p)$ in the following form (see Becketti, 2013, p. 301, 399):

$$
y_{t}=\mu+\sum_{i}^{p} \Phi_{i} y_{t-1}+\varepsilon_{t}
$$

where: vector of variables $y_{t}=\left[\begin{array}{ll}\Delta \mathrm{x}_{i t} & \Delta \mathrm{z}_{i t}\end{array}\right]^{\prime}, p$ - number of lags, $\mu$ - vector of constants, $\Phi_{i}$ - matrices of coefficients, $\varepsilon_{t}-$ vector of random disturbances.

The first differences of variables $\left(x_{i t}-\right.$ index, $z_{i t}-$ gold price) included in the research are the monthly logarithmic rates of return on $i$-th stock index $\left(\Delta \mathrm{x}_{\mathrm{it}}\right)$ and on investments in gold $\left(\Delta z_{\mathrm{it}}\right)$ calculated for the three considered countries on the basis of stock indices and gold prices.

To adjust the VAR model to the empirical data, we began by examining the order of log prices integration with the use of the ADF test (the Augmented Dickey-Fuller Unit Root Test (Mills, 2015, pp. 62-63). When the first order of time series integration was determined, we finished by taking the first differences of logarithms as our variables. The differentiation of series made it possible to obtain stationary variables which area prerequisite for applying the VAR model.

The next step involved testing for cointegration. Transforming a VAR model based on first differences of variables to VECM representation depends on the existence of cointegration between pairs of non-stationary variables I(1), characterizing markets in the analysed countries (stock index and gold price). The null hypothesis of the Johansen test assuming no cointegration vectors $(\mathrm{H} 0: \mathrm{r}=0)$ is tested against an alternative hypothesis $(\mathrm{H} 1: \mathrm{r} \leq 1)$. If the null hypothesis is rejected, the procedure should be continued for higher ranks $r$ until the number of cointegrating vectors describing the long run 
relationship in the VECM model is indicated. On the other hand, the acceptance of the null hypothesis $(r=0)$ implies the estimation of VAR model without ECM mechanism (Johansen \& Juselius, 1990; Charemza \& Deadman, 1997, p. 129, 175). We compare Trace and Max statistics with 5\% critical value, and additionally use the information criterion SBIC, HQIC and AIC to verify the hypothesis.

We chose the optimal number of lags on the basis of the LR - likelihood ratio, FPE - final prediction error, AIC - Akaike's information criterion, HQIC - Hannan and Quinn's information criterion, and SBIC - Schwarz's Bayesian information criterion. Moreover, we checked whether our VARs obeyed the stability condition (the multiple variable test for stationarity). We also performed the tests for normality and autocorrelation of residuals.

While investigating Granger causality, we used the Wald Test to check zero constraints on the estimated $\operatorname{VAR}(\mathrm{p})$ coefficients for each equation separately as presented by Lütkepohl (2005, p. 45, 102-103). In our two-dimensional VAR models, equation 1 concerns the investigation of causality from gold returns to stock index rates of return, and equation 2 - in the opposite direction. All calculations were conducted in STATA/IC $15^{\circledR}$. The advantage of VAR approach is that all variables can be treated symmetrically as we do not a priori divide variables into endogenous and exogenous. We can assume that the time path of $y_{t}$ is determined by current and previous realizations of $z_{t}$ and vice versa. Reasoning for such an approach was presented in detail by Sims (1980). Results can be sensitive to the number of lags set during estimation of models.

In this paper, we analyse the causal relationship between stock and gold markets in Poland, Hungary and the Czech Republic. The data used in this study consists of the following stock markets indices: WIG20, BUX, PX and gold prices in domestic currencies: PLN, HUF, CZK, respectively. We decided to select the aforementioned indices as they reflect the portfolio of the most liquid stocks, so-called blue chip shares on considered stock exchanges and can attract investors. WIG20 is a price index based on the value of portfolio with shares in 20 major and most liquid companies in the WSE Main List and it has been calculated since April 16, 1994. BUX is a BSE total return equity index of large cap (blue chip) companies, which consists of a variable number of shares (max. 25) calculated since January 2, 1991. PX is the official price index of PSE which replaced on March 20, 2006 the PX 50 and PX-D indices and took over the historical values of PX50 (first lunch on April 5, 1994). ${ }^{2}$

The study sample covers the period from December 1996 to December 2020, divided into two sub-samples: the pre-financial crisis (December 1996 - June 2007) and the next period (July 2007 - December 2020, including the crisis of 2007 and the beginnings of the ongoing COVID-19 pandemic). The descriptive statistics of empirical data (entire sample) is presented in Table 2.

\footnotetext{
2 Compare: WIG20 Factsheet; BUX index profile, PX index profile.
} 
Pobrane z czasopisma Annales H - Oeconomia http://oeconomia.annales.umcs.pl Data: 26/04/2023 06:29:40

Table 2. Descriptive statistics of time series in period 1996-2020 (end of month)

\begin{tabular}{|l|r|r|r|r|r|r|}
\hline \multicolumn{1}{|c|}{ Statistics } & \multicolumn{1}{c|}{ WIG20 } & \multicolumn{1}{c|}{ BUX } & \multicolumn{1}{c|}{ PX } & \multicolumn{1}{c|}{ GoldPLN } & \multicolumn{1}{c|}{ GoldHUF } & \multicolumn{1}{c|}{ GoldCZK } \\
\hline Mean & 2095.10 & 19362.95 & 925.23 & 3046.60 & 214522.50 & 19976.19 \\
\hline Std. Dev. & 586.80 & 10635.71 & 361.44 & 1794.00 & 140003.60 & 9692.37 \\
\hline Std. Dev./Mean & 0.2801 & 0.5493 & 0.3907 & 0.5889 & 0.6526 & 0.4852 \\
\hline Skewness & 0.4840 & 0.5538 & 0.3867 & 0.4200 & 0.5547 & 0.4443 \\
\hline Kurtosis & 3.1530 & 2.4082 & 2.7865 & 1.8900 & 2.2580 & 1.9103 \\
\hline
\end{tabular}

Source: Author's own study.

Empirical data on the indices were retrieved from the official statistics of the Warsaw Stock Exchange (WSE, Year Book), the Budapest Stock Exchange (BSE) and the Prague Stock Exchange (Yearly Fact Book and Monthly Statistics), while the data on gold price in USD and exchange rates were obtained from the World Gold Council and financial portal stooq.pl, respectively.

\section{Results}

The Augmented Dickey-Fuller Unit Root Test (ADF) statistics and the interpolated estimates of $1 \%, 5 \%$, and $10 \%$ critical values are shown in Table 3 . We also present MacKinnon approximate $p$-value of ADF below. The time series of stocks indices and gold prices of the analysed countries expressed in logarithms are non-stationary as we accept the null hypothesis of a unit root at all significance levels. After differentiation of variables, the first differences we obtain are stationary series, i.e. the null hypothesis of unit root is rejected. We conclude that the analysed times series are characterised by the first order of integration. ${ }^{3}$

Table 3. Z(t) statistics of Augmented Dickey-Fuller test for a unit root

\begin{tabular}{|c|c|c|c|c|c|c|c|c|c|}
\hline \multirow[b]{2}{*}{$\mathrm{Z}(\mathrm{t})$ stat. } & \multicolumn{2}{|c|}{ Model 1} & \multicolumn{2}{|c|}{ Model 2} & \multicolumn{2}{|c|}{ Model 3} & \multicolumn{3}{|c|}{ Critical value } \\
\hline & WIG20 & $\begin{array}{l}\text { Gold- } \\
\text { PLN }\end{array}$ & BUX & $\begin{array}{l}\text { Gold- } \\
\text { HUF }\end{array}$ & PX & $\begin{array}{l}\text { Gold- } \\
\text { CZK }\end{array}$ & $1 \%$ & $5 \%$ & $10 \%$ \\
\hline Logarithm & $-2.374^{\text {a) }}$ & $-2.393^{b)}$ & $-2.687^{\mathrm{d})}$ & $-2.287^{\mathrm{e})}$ & $-1.549^{f)}$ & $-2.673^{\mathrm{g})}$ & \multirow{2}{*}{-3.988} & \multirow{2}{*}{-3.428} & \multirow{2}{*}{-3.13} \\
\hline $1^{\text {st }}$ difference ${ }^{\text {c) }}$ & -16.772 & -17.232 & -15.579 & -7.824 & -15.506 & -18.887 & & & \\
\hline
\end{tabular}

Note: MacKinnon approximate $p$-value for $Z(\mathrm{t})$ is: a) 0.3933 , b) $0.3834,{ }^{\text {c) }} 0.0000,{ }^{\text {d) }} 0.2416,{ }^{\text {e) }} 0.4409,{ }^{\text {f }} 0.8118$, g) 0.2476 Source: Author's own study.

The results of the Johansen tests presented in Table 4 confirm the lack of a longterm relationship between pairs of variables characterising the markets in the analysed countries as we cannot reject null hypothesis that the VECM contains zero cointegrating relationship $\left(\operatorname{rank} r\right.$ of $\left.\alpha \beta^{\prime}=0\right)$ ). The conversion of the VAR representation of time

3 The results are also confirmed by the Phillips-Perron test of a unit root. 
series to the model with an error correction mechanism (ECM) is not necessary. The model can be estimated as a pure VAR on first differences of logarithms - monthly rates of returns.

Table 4. The results of the Johansen tests for cointegration

\begin{tabular}{|c|c|c|c|c|c|c|c|c|c|c|}
\hline \multirow{2}{*}{$\begin{array}{l}\text { Max. } \\
\text { rank }\end{array}$} & \multirow{2}{*}{$\begin{array}{c}\text { Param- } \\
\text { eters }\end{array}$} & \multirow{2}{*}{ LL } & \multirow{2}{*}{$\begin{array}{l}\text { Eigen- } \\
\text { value }\end{array}$} & \multicolumn{4}{|c|}{ Statistics / Critical value } & \multicolumn{3}{|c|}{ Information criterion } \\
\hline & & & & Trace & $5 \%$ & Max & $5 \%$ & SBI & HQIC & $\mathrm{AIC}$ \\
\hline \multicolumn{11}{|c|}{ Model 1 (Poland: WIG20, GoldPLN) } \\
\hline 0 & 6 & 801.70 & & $6.8417^{*}$ & 15.41 & 6.6543 & 14.07 & $-5.47 *$ & $-5.51 *$ & -5.54 \\
\hline 1 & 9 & 805.02 & 0.02292 & 0.1874 & 3.76 & 0.1874 & 3.76 & -5.43 & -5.50 & -5.55 \\
\hline 2 & 10 & 805.12 & 0.00065 & & & & & -5.41 & -5.49 & -5.54 \\
\hline \multicolumn{11}{|c|}{ Model 2 (Hungary: BUX, GoldHUF) } \\
\hline 0 & 6 & 800.07 & & $9.0403 *$ & 15.41 & 8.8400 & 14.07 & $-5.47 *$ & $-5.51 *$ & -5.54 \\
\hline 1 & 9 & 804.49 & 0.03033 & 0.2003 & 3.76 & 0.2003 & 3.76 & -5.43 & -5.50 & -5.55 \\
\hline 2 & 10 & 804.60 & 0.00070 & & & & & -5.41 & -5.49 & -5.54 \\
\hline \multicolumn{11}{|c|}{ Model 3 (The Czech Republic: PX, GoldCZK) } \\
\hline 0 & 6 & 840.40986 & & $5.0779 *$ & 15.41 & 4.6018 & 14.07 & $-5.47 *$ & $-5.51 *$ & -5.54 \\
\hline 1 & 9 & 842.71076 & 0.01591 & 0.4761 & 3.76 & 0.4761 & 3.76 & -5.43 & -5.50 & -5.55 \\
\hline 2 & 10 & 842.94881 & 0.00166 & & & & & -5.41 & -5.49 & -5.54 \\
\hline
\end{tabular}

Source: Author's own study.

As justified above, the further research was conducted on the basis of VAR models estimated for first differences of variables (logarithmic rates on returns, $R$ ) without an ECM component. The recommended number of lags (asterisk, Table 5) in the VAR form of the model was 1 for Poland (all selection order criteria), and 1 (LL, FPE,) or 2 (HQIC, SBIC) in the case of Hungary and the Czech Republic.

Table 5. Number of lags by information criterion of models for Poland, Hungary and the Czech Republic

\begin{tabular}{|c|c|c|c|c|c|c|c|c|}
\hline Lag & LL & LR & df & $\mathrm{P}$ & FPE & $\mathrm{AIC}$ & HQIC & SBIC \\
\hline \multicolumn{9}{|c|}{ Model 1 (Poland) } \\
\hline 0 & -290.971 & & & & 0.026788 & 2.05594 & 2.06621 & 2.08157 \\
\hline 1 & 797.620 & 2177.2* & 4 & 0.000 & 0.000013* & $-5.55523 *$ & $-5.5244 *$ & $-5.47833 *$ \\
\hline 2 & 799.531 & 3.8231 & 4 & 0.430 & 0.000013 & -5.54057 & -5.48919 & -5.41241 \\
\hline \multicolumn{9}{|c|}{ Model 2 (Hungary) } \\
\hline 0 & -400.520 & & & & 0.057784 & 2.8247 & 2.83498 & 2.85034 \\
\hline 1 & 792.367 & 2385.8 & 4 & 0.000 & 0.000014 & -5.51837 & $-5.48754 *$ & $-5.44147 *$ \\
\hline 2 & 798.497 & $12.259 *$ & 4 & 0.016 & $0.000014 \%$ & $-5.53331 *$ & -5.48194 & -5.40516 \\
\hline \multicolumn{9}{|c|}{ Model 3 (The Czech Republic) } \\
\hline 0 & -323.12 & & & & 0.033567 & 2.28155 & 2.29182 & 2.30718 \\
\hline 1 & 832.54 & 2311.3 & 4 & 0.000 & 0.00001 & -5.80028 & $-5.76945 *$ & $-5.72338 *$ \\
\hline 2 & 838.21 & $11.34 *$ & 4 & 0.023 & $0.00001 *$ & $-5.812 *$ & -5.76062 & -5.68384 \\
\hline
\end{tabular}

* optimal number of lags

Source: Author's own study. 
The results of the Jarque-Bera test confirm the lack of normal distribution of model's equation residuals. The Lagrange-multiplier test indicates no evidence of autocorrelation since we cannot reject the null hypothesis of no residual autocorrelations at any significance levels. All estimated VAR models satisfy stability conditions as the eigenvalues of the companion matrix lie inside the unit circle (Table 6).

Table 6. The Jarque-Bera normality test, Lagrange-multiplier autocorrelation test for models' residuals and VAR(1) eigenvalues for Poland, Hungary and the Czech Republic

\begin{tabular}{|c|c|c|c|c|c|c|c|c|c|}
\hline \multirow{2}{*}{ Equation } & \multicolumn{3}{|c|}{ VAR returns for Poland } & \multicolumn{3}{|c|}{ VAR returns for Hungary } & \multicolumn{3}{|c|}{$\begin{array}{l}\text { VAR returns for the Czech } \\
\text { Republic }\end{array}$} \\
\hline & WIG20 & $\begin{array}{l}\text { Gold- } \\
\text { PLN }\end{array}$ & ALL & BUX & $\begin{array}{l}\text { Gold- } \\
\text { HUF }\end{array}$ & ALL & PX & $\begin{array}{l}\text { Gold- } \\
\text { CZK }\end{array}$ & ALL \\
\hline$\chi^{2}$ & 96.147 & 25.142 & 121.3 & 481.48 & 60.83 & 542.31 & 154.38 & 20.73 & 175.1 \\
\hline df & 2 & 2 & 4 & 2 & 2 & 4 & 2 & 2 & 4 \\
\hline Prob. $>\chi^{2}$ & 0.0000 & 0.00000 & 0.0000 & 0.0000 & 0.00000 & 0.0000 & 0.0000 & 0.00003 & 0.000 \\
\hline LM/lags & $\chi^{2}$ & df & $\begin{array}{c}\text { Prob. } \\
>\chi^{2}\end{array}$ & $\chi^{2}$ & df & $\begin{array}{c}\text { Prob. } \\
>\chi^{2}\end{array}$ & $\chi^{2}$ & df & $\begin{array}{c}\text { Prob. } \\
>\chi^{2}\end{array}$ \\
\hline 1 & 1.2327 & 4 & 0.87269 & 4.5190 & 4 & 0.34030 & 2.2592 & 4 & 0.68820 \\
\hline 2 & 2.1008 & 4 & 0.71722 & 5.4213 & 4 & 0.24674 & 4.6316 & 4 & 0.32723 \\
\hline Eigenvalue & \multicolumn{3}{|c|}{$-0.08629449 ; 0.04123202$} & \multicolumn{3}{|c|}{$0.1122179 ;-0.1005883$} & \multicolumn{3}{|c|}{$-0.1353626 ; 0.08032498$} \\
\hline
\end{tabular}

Source: Author's own study.

Statistics of the Granger causality Wald test shown in Table 7 are based on VAR(1). Type of causality was analysed in both directions (equation 1, 2). Unidirectional causality from gold returns to stock returns is present only in the case of Hungary and the Czech Republic. The null hypothesis of the lack of the unilateral causality is rejected at significance level $\alpha=5 \%$, i.e. gold market has an impact on stock market in these countries. The causality in the opposite direction does not exist.

Table 7. Granger causality Wald test results for the entire sample

\begin{tabular}{|l|l|l|c|c|c|l|}
\hline \multicolumn{1}{|c|}{ Model } & \multicolumn{1}{|c|}{ Equation } & \multicolumn{1}{c|}{ Excluded } & $\chi^{2}$ & df & Prob. $>\chi^{2}$ & \multicolumn{1}{|c|}{ Type of causality } \\
\hline \multirow{2}{*}{ 1. Poland } & 1: R_WIG20 & R_GoldPLN; ALL & 2.3985 & 1 & 0.121 & NO: independence \\
\cline { 2 - 7 } & 2: R_GoldPLN & R_WIG20; ALL & 0.49104 & 1 & 0.483 & NO: independence \\
\hline \multirow{2}{*}{ 2. Hungary } & 1: R_BUX & R_GoldHUF; ALL & 5.278 & 1 & $\mathbf{0 . 0 2 2} *$ & YES: unidirectional \\
\cline { 2 - 7 } & 2: R_GoldHUF & R_BUX; ALL & 0.79983 & 1 & 0.371 & NO: independence \\
\hline $\begin{array}{l}\text { 3. The Czech } \\
\text { Republic }\end{array}$ & 1: R_PX & R_GoldCZK; ALL & 5.1094 & 1 & $\mathbf{0 . 0 2 4} *$ & YES: unidirectional \\
\cline { 2 - 7 } & 2: R_GoldCZK & R_PX; ALL & 0.21807 & 1 & 0.641 & NO: independence \\
\hline
\end{tabular}

* significance level $\alpha=0.05$

Source: Author's own study.

In order to carry out an in-depth analysis of the relationship between the returns, the data are split into two samples, the pre-financial crisis (December 1996 to June 2007) and the next period (July 2007 to December 2020), including the crisis of 2007 and the beginnings of the ongoing COVID-19 pandemic. In Table 8, we present the results of Panel A - a pre-crisis period and Panel B - a period since July 2007, respectively. 
We show that in the first sub-period (Panel A), there are no causal relationships between the analysed markets. As for the second sub-period (Panel B), we indicate that gold returns determine stock returns in two countries, namely Poland and Hungary. Thus, only in Hungary is the impact of gold on the stock market observed both in the entire period and the second sub-period. In this respect, the research hypothesis of unidirectional causality was positively verified.

Table 8. The Granger causality Wald test results for sub-periods

\begin{tabular}{|c|c|c|c|c|c|c|}
\hline Model & Equation & Excluded & $\chi^{2}$ & $\mathrm{df}$ & Prob. $>\chi^{2}$ & Type of causality \\
\hline \multicolumn{7}{|c|}{ Panel A } \\
\hline \multirow{2}{*}{ 1. Poland } & 1:R_WIG20 & R_GoldPLN; ALL & 0.02771 & 1 & 0.868 & NO: independence \\
\hline & 2: R_GoldPLN & R_WIG20; ALL & 0.18038 & 1 & 0.671 & NO: independence \\
\hline \multirow{2}{*}{ 2. Hungary } & 1: R_BUX & R_GoldHUF; ALL & 0.01766 & 1 & 0.894 & NO: independence \\
\hline & 2: R_GoldHUF & R_BUX; ALL & 0.12961 & 1 & 0.719 & NO: independence \\
\hline \multirow{2}{*}{$\begin{array}{l}\text { 3. The Czech } \\
\text { Republic }\end{array}$} & 1: R_PX & R_GoldCZK; ALL & 0.36108 & 1 & 0.548 & NO: independence \\
\hline & 2: R_GoldCZK & R_PX; ALL & 0.29794 & 1 & 0.585 & NO: independence \\
\hline \multicolumn{7}{|c|}{ Panel B } \\
\hline \multirow{2}{*}{ 1. Poland } & 1: R_WIG20 & R_GoldPLN; ALL & 4.57090 & 1 & $0.033 *$ & YES: unidirectional \\
\hline & 2: R_GoldPLN & R_WIG20; ALL & 1.76930 & 1 & 0.183 & NO: independence \\
\hline \multirow{2}{*}{ 2. Hungary } & 1:R_BUX & R_GoldHUF; ALL & 4.76330 & 1 & $0.029 *$ & YES: unidirectional \\
\hline & 2: R_GoldHUF & R_BUX; ALL & 0.88074 & 1 & 0.348 & NO: independence \\
\hline \multirow{2}{*}{$\begin{array}{l}\text { 3. The Czech } \\
\text { Republic }\end{array}$} & 1:R_PX & R_GoldCZK; ALL & 1.68410 & 1 & 0.194 & NO: independence \\
\hline & 2: R_GoldCZK & R_PX; ALL & 0.42057 & 1 & 0.517 & NO: independence \\
\hline
\end{tabular}

* significance level $\alpha=0.05$

Source: Author's own study.

\section{Discussion}

The subject of research in this paper is the markets of the three countries which were not the field of interest of other authors, apart from Poland. In the case of Poland, we show that there is no Granger causality between WIG20 and gold returns in either direction and there is lack of cointegration (no long-term equilibrium). The gold market does not impact on stock market returns and vice versa. The findings are consistent with the results covering a similar period (1997-2018) presented by Mamcarz (2019). Also the findings of research devoted to countries which were not considered in our paper were similar to those in India (Bhuvaneshwari \& Ramya, 2017), Germany (Al-Ameer et al., 2018), and Malaysia (Hussin et al., 2013). However, these researchers achieved mixed results in the case of testing cointegration, which determined the selection of the final model form.

In the case of the two remaining countries under analysis in this paper (Hungary and the Czech Republic), the Granger causality runs from gold to stock. The same unilateral relationship is also identified on other markets, e.g. in India as shown by Patel (2013) or in selected countries associated in GCC, as documented by Al Kharusi and Basci (2019). It means that changes on the gold market determine the situation on 
the stock market. The reverse direction of the relationship is also possible (Miyazaki $\&$ Hamori, 2013). This shows that investors are transferring capital to markets that are more profitable at a given time.

Similarly to other authors, we divide our sample into two sub-periods, the first one before the 2007 financial crisis and the second one covering this crisis and the beginning of the ongoing COVID-19 pandemic. We achieve mixed results concerning the two types of causality: independence vs. unidirectional, depending on the sub-periods in two countries, Poland and Hungary. This pattern is also documented by Tiwari et al. (2019). They also split the entire period from January 2002 to July 2018 into sub-periods, before and after the crisis. They show that no causal relationships were found in the period preceding the crisis, whereas in the period after the crisis, causality in the direction from gold to stocks was revealed in some of the markets. The overall results were similar, except for those obtained for Turkey, China and Indonesia.

We do not find any feedback causality in the sub-samples mentioned above. However, such dependences are reported on other markets. For instance, Choudhry et al. (2015) analysed the interrelations in the United Kingdom, the United States and Japan in the period between January 2000 and March 2014. According to the authors, the data are split into two samples, the pre-financial crisis (January 2000 to June 2007) and the financial crisis period (July 2007 to March 2014). A significant non-linear bilateral correlation was identified between gold and stock market during the crisis period, as opposed to the preceding period. Before the crisis, a causal relationship was only significant in the UK, while Japan was an exception during the crisis. The findings confirm that these causal interrelations can be affected by financial crisis in a different way, which was proved by various methods applied (VAR, GARCH vs. QQ regression).

\section{Conclusions}

In this paper, we analysed the Granger causality between the rates of return on investments on the stock markets in the three Central and East European countries, namely Poland, Hungary and the Czech Republic, and the rates of return on gold, examined by applying the VAR model.

We show that, apart from the two instances of unilateral causality, no causal relationship was found in any of the directions. Only in the case of Hungary and the Czech Republic (significant at $\alpha=5 \%$ ), did the rate of return on the gold market determine the rates of return on the stock markets, whereas in Poland no such causality was identified. To some extent, the research hypothesis was positively verified for the entire sample. The results confirm that the changes in the stock market prices in the three considered countries did not affect the change in the price of gold. While analysing the sub-periods, we state that stock returns in Poland and Hungary are determined by changes in gold prices only in the second sub-period. This is consistent with our hypothesis of the impact of gold on stock market occurring during 
sub-periods under investigation. Only in Hungary is the impact of gold on the stock market observed both in the entire period and in the second sub-period.

The investors who would like to invest their funds in blue chip companies listed on stock exchanges of the analysed countries represented by selected indices: the Warsaw Stock Exchange - WIG20, the Budapest Stock Exchange - BUX index, and the Prague Stock Exchange - PX index can become familiar with the interrelations between gold-stock markets and can compare them to major global and geographical markets which have been widely discussed in the literature on this subject. The results of our research could be helpful for investors making rational investment decisions.

The research limitation of the study is that two out of three indices are price indices (WIG20, PX), whereas BUX is a total return index that could determine the levels of the achieved rates of returns between countries. Moreover, the different starting dates of index calculations and data availability have an impact on setting the starting point of our samples. We chose December 1996 for all three countries to satisfy the comparability of results.

There is no doubt that rally in gold market due to the COVID-19 pandemic lasted a relatively short time (i.e. the period from January to December 2020 covered in this paper) to largely determine the interrelations between the analysed markets. The economic slowdown and record high gold price in many currencies will affect the demand for gold in the long term. This issue will be the field of further research.

\section{References}

Açikalin, S., \& Başci, E.S. (2016). Cointegration and Causality Relationship between IST 100 and BIST Gold Indices. Journal of Management and Economics, 23(2), 565-574.

https://doi.org/10.18657/yecbu.53293

Al Kharusi, S., \& Basci, E.S. (2019). Cointegration and Causality between the GCC Stock Indices and Gold Indices. Business and Economic Horizons, 15(1), 60-69. https://doi.org/10.15208/beh.2019.4

Al-Ameer, M., Hammad, W., Ismail, A., \& Hamdan, A. (2018). The Relationship of Gold Price with the Stock Market: The Case of Frankfurt Stock Exchange. International Journal of Energy Economics and Policy, 8(5), 357-371.

Becketti, S. (2013). Introduction to Time Series Using Stata. College Station: Stata Press.

Beckmann, J., Berger, T., \& Czudaj, R. (2015). Does Gold Act as a Hedge or a Safe Haven for Stocks? A Smooth Transition Approach. Economic Modelling, 48, 16-24.

https://doi.org/10.1016/j.econmod.2014.10.044

Bhuvaneshwari, D., \& Ramya, K. (2017). Causal Relationship between Stock Prices and Gold Rate: Empirical Evidence from India. Afro-Asian Journal of Finance and Accounting, 7(4).

https://doi.org/10.1504/AAJFA.2017.087502

BUX index profile. Retrieved from https://www.bse.hu/Products-and-Services/Indices/BUX

Charemza, W.W., \& Deadman, D.F. (1997). New Directions in Econometric Practice. General to Specific Modelling, Cointegration and Vector Autoregression. Cheltenham - Northampton: Edward Elgar.

Choudhry, T., Hassan, S.S., \& Shabi, S. (2015). Relationship between Gold and Stock Markets During the Global Financial Crisis: Evidence from Nonlinear Causality Tests. International Review of Financial Analysis, 41, 247-256. https://doi.org/10.1016/j.irfa.2015.03.011 
GFMS Gold Survey. (2019). REFINITIV. Retrieved from https://solutions.refinitiv.com/metalsresearch

Gokmenoglu, K.K., \& Fazlollahi, N. (2015). The Interactions among Gold, Oil, and Stock Market: Evidence from S\&P 500. Procedia - Economics and Finance, 25, 478-488.

https://doi.org/0.1016/S2212-5671(15)00760-1

Hemavathy, P., \& Gurusamy, S. (2016). Testing the Causality and Cointegration of Gold Price and NSE (S\&P CNX NIFTY): Evidence from India. Amity Global Business Review, 11.

Hussin, M.Y.M., Muhammad, F., Razak, A.A., Tha, G.P., \& Marwan, N. (2013). The Link between Gold Price, Oil Price and Islamic Stock Market: Experience from Malaysia. Journal of Studies in Social Sciences, 4(2), 161-182.

Johansen, S., \& Juselius, K. (1990). Maximum Likelihood Estimation and Inference on Cointegration with Applications to the Demand for Money. Oxford Bulletin of Economics \& Statistic, 52(2), 169-210. https://doi.org/10.1111/j.1468-0084.1990.mp52002003.x

Lütkepohl, H. (2005). New Introduction to Multiple Time Series Analysis. Berlin: Springer.

Mamcarz, K. (2019). Gold Market and Selected Stock Markets - Granger Causality Analysis. In W. Tarczyński \& K. Nermend (Eds.), Effective Investments on Capital Markets. Springer Proceedings in Business and Economics (pp. 405-422). Cham: Springer.

https://doi.org/10.1007/978-3-030-21274-2_28

Mills, T.C. (2015). Time Series Econometrics: A Concise Introduction. Basingstoke: Palgrave Macmillan.

Mishra, P.K., Das, J.R., \& Mishra, S.K. (2010). Gold Price Volatility and Stock Market Returns in India. American Journal of Scientific Research, 9(9).

Miyazaki, T., \& Hamori, S. (2013). Testing for Causality between the Gold Return and Stock Market Performance: Evidence for 'Gold Investment in Case of Emergency'. Applied Financial Economics, 23(1), 27-40. https://doi.org/10.1080/09603107.2012.699184

Patel, S.P. (2013). Causal Relationship between Stock Market Indices and Gold Price: Evidence from India. The IUP Journal of Applied Finance, 19.

PX index profile. Retrieved from https://www.pse.cz/en/indices/index-values/detail/XC0009698371

Sims, C. (1980). Macroeconomics and Reality. Econometrica, 48(1), 1-48. https://doi.org/10.2307/1912017

Tiwari, A.K., Adewuyi, A.O., \& Roubaud, D. (2019). Dependence between the Global Gold Market and Emerging Stock Markets (E7+1): Evidence from Granger Causality Using Quantile and Quantile-on-Quantile Regression Methods. The World Economy, 42(7), 2172-2214.

https://doi.org/10.1111/twec.12775

WIG20 Index factsheet. Retrieved from https://gpwbenchmark.pl/en-karta-indeksu?isin=PL9999999425

\section{Data sources}

The Budapest Stock Exchange. Retrieved from https://www.bse.hu/pages/data-download

The Prague Stock Exchange Monthly Statistics. Retrieved from https:/www.pse.cz/en/market-data/statistics/ statistics-files?tab=stat-monthly

The Prague Stock Exchange Yearly Fact Book. Retrieved from https://www.pse.cz/en/market-data/statistics/ statistics-files?tab=stat-yearly

The Warsaw Stock Exchange Year Book. Retrieved from https://www.gpw.pl/biblioteka-gpw-lista?gpwlc_id $=10 \&$ publication_date_from $=\& q u e r y=\&$ publication_date_to $=\& p h \_$main_02_offset $=0$

The World Gold Council (WGC). Retrieved from https://www.gold.org

USD/CZK exchange rate. Retrieved from $h t t p s: / / s t o o q . p l / q / d / ? s=u s d c z k$

USD/HUF exchange rate. Retrieved from https://stooq.pl/q/d/? $\mathrm{s}=$ usdhuf

USD/PLN exchange rate. Retrieved from https://stooq.pl/q/d/?s=usdpln 